\title{
Options for REDD+ Voluntary Certification to Ensure Net GHG Benefits, Poverty Alleviation, Sustainable Management of Forests and Biodiversity Conservation
}

\author{
Eduard Merger ${ }^{1}$, Michael Dutschke ${ }^{2}$ and Louis Verchot ${ }^{3, *}$ \\ 1 Unique GmbH, Schnewlinstrasse 10, 79098 Freiburg, Germany; \\ E-Mail: eduard.merger@ unique-forst.de \\ 2 Biocarbon Consult, Badstr. 41, 77652 Offenburg, Germany; E-Mail: michael@ biocarbon.net \\ 3 Center for International Forestry Research, Situ Gede, Jalan CIFOR, 16000 Bogor, Indonesia \\ * Author to whom correspondence should be addressed; E-Mail: 1.verchot@ cgiar.org; \\ Tel.: +62-81-1199-0044; Fax: +62-251-8622-100.
}

Received: 9 February 2011; in revised form: 5 April 2011 / Accepted: 6 April 2011 /

Published: 27 April 2011

\begin{abstract}
Our objective was to compare and evaluate the practical applicability to REDD+ of ten forest management, social, environmental and carbon standards that are currently active worldwide: Climate, Community and Biodiversity (CCB), CCB REDD+ Social and Environmental Standards (CCBA REDD+ S\&E), CarbonFix Standard (CFS), Forest Stewardship Council (FSC), Global Conservation Standard (GCS), ISO 14064:2006, Plan Vivo Standard, Programme for Endorsement of Forest Certification (PEFC), SOCIALCARBON Standard and the Voluntary Carbon Standard (VCS). We developed a framework for evaluation of these standards relative to each other using four substantive criteria: (1) poverty alleviation, (2) sustainable management of forests (SMF), (3) biodiversity protection, (4) quantification and assessment of net greenhouse gas (GHG) benefits; and two procedural criteria: (5) monitoring and reporting, and (6) certification procedures. REDD programs require assessment of GHG benefits, monitoring, reporting and certification. Our analysis shows that only the Voluntary Carbon Standard (VCS) treats these three criteria comprehensively. No standard provides comprehensive coverage of the social and other environmental criteria. FSC, PEFC and CarbonFix provide comprehensive assessments of the sustainable forest management criterion. CCBA REDD+ S\&E, CCB, and GCS provide comprehensive coverage of the biodiversity and poverty alleviation criteria. Experience in using these standards in pilot projects shows that projects are
\end{abstract}


currently combining several standards as part of their strategy to improve their ability to attract investment, but costs of implementing several certification schemes is a concern. We conclude that voluntary certification provides useful practical experience that should feed into the design of the international REDD+ regime.

Keywords: voluntary forest certification; forest carbon standard; SMF; biodiversity conservation; REDD+ safeguards

\section{Introduction}

Land use-based emission reduction and carbon uptake mechanisms such as reducing emissions from deforestation and forest degradation, and sustainable management of forests (SMF) can offer relatively inexpensive options for mitigating the accumulation of greenhouse gases (GHGs) in the atmosphere [1]. To mobilize sufficient capital, hopes have centered on cap-and-trade systems under the UN Framework Convention on Climate Change (UNFCCC) with opportunities for offsets in tropical forestry. The precondition for this to function is a regulated market. At the 2007 meeting in Bali of the Parties (Signatories) to the UNFCCC it was decided to implement a mechanism called "Reducing Emissions from Deforestation and forest Degradation" (REDD, respectively REDD+, to include forest conservation and the human-induced increase of forest carbon stocks) under the Convention.

Since 2004, some limited experience with land-based mitigation projects has been gained through afforestation and reforestation (A/R) activities under the Clean Development Mechanism (CDM). The UNFCCC agreed on the modalities of A/R CDM projects at the 9th Conference of the Parties (CoP 9) in Milan in December 2003. At that time, the European Union fought for the introduction of a set of social and environmental safeguards to be independently verified by designated operational entities, very much in the fashion of a binding international standard. This aspiration ignored country-specific social and environmental circumstances of natural resource management.

There has been considerable concern that offset mechanisms provide social and environmental benefits in addition to the offsets in the countries that host activities under these programs. This was embodied in the decision at COP 9 on modalities for implementing CDM afforestation and reforestation $(\mathrm{A} / \mathrm{R})$ activities, where the responsibility for ensuing that this was indeed the case was left to the host country. The decision requires that comprehensive impact assessments be carried out in accordance with the national requirements [2]. With respect to the non-permanence potential of forest related sinks, the decision ensures that local communities are protected by requiring the buyer to be held liable for any eventual losses of sequestered carbon [3].

Seven years later, amid the ongoing debate on REDD, the scope has gradually widened to REDD+ to include SMF, forest conservation and enhancement of carbon stocks in forests. The preamble to the decision taken by the Ad hoc Working Group on Long-term Cooperative Action in Cancún includes principles and safeguards such as protection of local and indigenous community rights, broad participation within countries, support for adaptation benefits, good governance, poverty reduction, and biodiversity conservation [4]. The European Union proposed monitoring, reporting, and 
verification (MRV) of country compliance with these principles and safeguards. The language that was finally accepted was considerably weaker, but leaves open this possibility.

In addition to the climate change negotiations in the UNFCCC, civil society has been proactive in this area. This has resulted in the proliferation of numerous voluntary forest and carbon certification schemes, beginning with the inception of the Forest Stewardship Council (FSC) in 1993, and several GHG accounting, social and environmental standards for forest-based climate change mitigation activities in the middle of this decade. These standards have had a range of objectives, such as promotion of SMF; quantification, monitoring, and verifying of emission reductions from deforestation and enhancement of carbon removals from the atmosphere; poverty alleviation; and biodiversity conservation, seeking to promote credible forest carbon projects for the voluntary carbon markets. In contrast to internationally agreed norms, such standards create uniformity of principles and criteria without challenging host countries' national sovereignty, as their application is strictly voluntary. However, as each standard has its own specific attributes, there is no single consistent and widely accepted framework for SMF and forest carbon standards that grant real, additional, permanent GHG benefits and that at the same time can "ensure the integrity of existing forests, protect biodiversity and promote a range of other environmental and social values" [5].

A number of studies have been published on different aspects of implementation of standards [6-10]; however, these have not assessed the practicalities with respect to forest carbon projects. The objective of this paper is to review the ten most popular and appropriate certification schemes that focus on standardizing GHG accounting and ensuring social and environmental performance of projects and to assess their applicability to REDD+ activities on national and subnational levels.

Initially we develop a set of criteria against which we compare and evaluate each standard's principles and criteria, the level of performance required, and the degree of overlap between standards. The paper is directed to project developers who are considering using a standard, either to procure services (e.g., MRV or positive social or environmental performance) or market their projects. Carbon buyers or project sponsors who want to understand the variety of standards proposed to ensure the integrity of forest management or conservation activities will also find this information valuable. Subsequently, we examine concrete project experiences applying land use standards as an example of how they operate in practice. We conclude with recommendations on improving the schemes' overall credibility and efficacy through combination and strategic alliances with other schemes.

\section{Assessment and Evaluation Approach}

The certification schemes act on different levels, serve different stakeholder groups, and thus must reflect a variety of stakeholder views in their setup [11]. There is a methodological difficulty comparing different certification schemes that are implemented at different levels and spatial scales [12]. In order to assess the potential of the different forest standards and to identify effective and efficient criteria and procedures of the standards, we will initially summarize the general standards background, objectives, their applicability, their level of certified area, providing an overview of the standards. Subsequently, we develop six assessment criteria based on the WWF Forest Carbon Standards Assessment Guide [5] which was developed by an expert panel, the Forest Carbon Advisory Committee, representing private and non-governmental actors. This framework developed principles 
for high-quality forest carbon standards and provided an assessment framework for the comprehensiveness of forest carbon projects.

\subsection{Background and Objectives}

Table 1 presents an overview of ten standards considered in this study and summarizes their background, objectives, their applicability, and their certified project areas.

\subsection{Assessment Criteria}

REDD+ will only succeed if projects and programs demonstrate that they can deliver multiple benefits including the protection of biodiversity; real, measurable, and verifiable GHG emission reductions and carbon removals; and contribute to poverty alleviation [13,14]. We draw on these crucial REDD+ components to develop a set of assessment criteria, against which we evaluate and discuss the major differences among the standards schemes. The assessment criteria were developed on the basis of the WWF forest carbon standards assessment guide for forest carbon standards and projects [5]. In addition, the assessment criteria were complemented by the review of the standard schemes. Based on this, six major criteria were developed that suggest the representation of the key components of a comprehensive and credible standard for the certification of REDD+ projects or programs. Among the six key components, we differentiate between four substantive criteria: poverty alleviation, SMF, biodiversity conservation, and accounting of GHG emission reductions; and two procedural criteria; monitoring and reporting, and the certification procedures.

\subsubsection{Poverty Alleviation}

Since REDD+ activities operate in very diverse and complex social and ecological environments, it is crucial that such activities do not negatively affect the local population and that they consider the rights of indigenous peoples or other local communities [5]. Thus, we assess whether and how the standards' application accounts for impacts outside the project areas. Moreover, we assess how projects or programs address the facilitation of capacity building such as knowledge transfer and employment generation, promote equitable benefit sharing mechanisms, and ensure food security. Also, we review how the standards treat land tenure; land use rights; and include indigenous peoples' rights, workers rights and legal compliance.

\subsubsection{Sustainable Management of Forest (SMF)}

In order to compare standards' principles and criteria in relation to SMF, we assess how the standards address the compliance of REDD+ activities with national forest policies, their requirements to develop long-term forest management plans at appropriate scale and intensity, and their approaches to maintain and protect ecosystem services such as water and soil. Furthermore, we assess how the different standards address the avoidance of converting natural forests to other land uses, and how the REDD+ activities can be integrated into overall land use planning. 
Table 1. Summary of standards' background and objectives.

\begin{tabular}{|c|c|c|c|c|}
\hline Standard & Background & Objectives & Applicability & $\begin{array}{c}\text { Certified projects/area by } \\
\text { December } 2010\end{array}$ \\
\hline $\begin{array}{c}\text { Forest Stewardship } \\
\text { Council (FSC) }\end{array}$ & $\begin{array}{l}\text { Founded in } 1993 \text { in order to stop } \\
\text { global deforestation by the WWF, } \\
\text { other environmental NGOs, timber } \\
\text { traders, indigenous peoples' groups } \\
\text { and forest worker organizations. }\end{array}$ & $\begin{array}{l}\text { Promotion of SMF and to achieve } \\
\text { environmentally appropriate, socially } \\
\text { responsible, and economically viable use } \\
\text { of forests. }\end{array}$ & $\begin{array}{l}\text { For use by private companies and } \\
\text { organizations that seek to } \\
\text { manage forests in an } \\
\text { economically, socially and } \\
\text { environmentally sustainable } \\
\text { manner. }\end{array}$ & $\begin{array}{l}\text { Represented in more than } \\
50 \text { countries. } \\
\text { Over } 131 \text { million ha of global } \\
\text { forests are certified (mostly in the } \\
\text { boreal and temperate zone of the } \\
\text { northern hemisphere). }\end{array}$ \\
\hline $\begin{array}{l}\text { Programme for the } \\
\text { Endorsement of } \\
\text { Forest Certification } \\
\text { (PEFC) }\end{array}$ & $\begin{array}{l}\text { Founded in } 1999 \text { as an umbrella } \\
\text { certification organization that } \\
\text { facilitates and endorses the } \\
\text { development of national or regional } \\
\text { forest certification systems. }\end{array}$ & $\begin{array}{l}\text { Promotion of SMF and ensure that } \\
\text { timber and non-timber products are } \\
\text { produced in compliance with ecological, } \\
\text { social, and ethical standards. }\end{array}$ & $\begin{array}{l}\text { Intended for use at subnational } \\
\text { and national scales by national } \\
\text { forest owners' organizations or } \\
\text { by national forestry } \\
\text { organizations. }\end{array}$ & $\begin{array}{l}\text { PEFC has certified more than } \\
232 \text { million ha of forests } \\
\text { In the tropics there are four national } \\
\text { standards: Australian Forestry } \\
\text { Standard, PAFC Gabon, Malaysian } \\
\text { Timber Certification Council } \\
\text { (MTCC), and CERFLOR (Brazil). }\end{array}$ \\
\hline $\begin{array}{l}\text { Climate, Community } \\
\text { and Biodiversity } \\
\text { (CCB) Standards }\end{array}$ & $\begin{array}{l}\text { Climate, Community and } \\
\text { Biodiversity Alliance (CCBA), is a } \\
\text { partnership between research } \\
\text { institutions, corporations, and } \\
\text { environmental groups since } 2005 \text {. }\end{array}$ & $\begin{array}{l}\text { Standards aim to provide flexible rules } \\
\text { and guidance for the development of } \\
\text { subnational land-based projects that } \\
\text { deliver climate, community and } \\
\text { biodiversity benefits in an integrated and } \\
\text { sustainable manner. }\end{array}$ & $\begin{array}{l}\text { Intended to be used by } \\
\text { project-developing organizations } \\
\text { using a project design guidance } \\
\text { framework. }\end{array}$ & $\begin{array}{l}32 \text { CCBA projects had been } \\
\text { successfully certified and } 18 \text { further } \\
\text { projects are currently in the third- } \\
\text { party validation stage. }\end{array}$ \\
\hline $\begin{array}{c}\text { CCBA REDD+ Social } \\
\text { and Environmental } \\
\text { Standards (CCBA } \\
\text { S\&E) }\end{array}$ & $\begin{array}{l}\text { Released by CCBA in June } 2010 \text { in } \\
\text { order to work towards a REDD+ } \\
\text { mechanism under the UNFCCC. }\end{array}$ & $\begin{array}{l}\text { Provision of effective social and } \\
\text { environmental quality criteria for } \\
\text { REDD+ and other forest carbon } \\
\text { programs that ensure human rights, } \\
\text { poverty reduction, and biodiversity } \\
\text { conservation. }\end{array}$ & $\begin{array}{l}\text { Applicable to government-led } \\
\text { programs at the national, state, } \\
\text { provincial, or regional level for } \\
\text { fund-based or market-based } \\
\text { REDD+ initiatives. }\end{array}$ & $\begin{array}{l}\text { In } 2010 \text { and } 2011 \text { pilot projects are } \\
\text { being tested in Nepal, Ecuador, and } \\
\text { Tanzania. }\end{array}$ \\
\hline
\end{tabular}


Table 1. Cont.

\begin{tabular}{|c|c|c|c|c|}
\hline Standard & Background & Objectives & Applicability & $\begin{array}{c}\text { Certified projects/area by } \\
\text { December } 2010\end{array}$ \\
\hline $\begin{array}{c}\text { CarbonFix } \\
\text { Standard (CFS) }\end{array}$ & $\begin{array}{l}\text { Launched in } 2007 \text { with support of } \\
\text { more than } 60 \text { organizations. }\end{array}$ & $\begin{array}{l}\text { Promotion that } \mathrm{A} / \mathrm{R} \text { projects in the voluntary } \\
\text { carbon market sequester carbon, restore } \\
\text { forests, and deliver benefits to people and the } \\
\text { environment in a practical, transparent and } \\
\text { comprehensive way. }\end{array}$ & $\begin{array}{l}\text { Used by A/R carbon projects- } \\
\text { currently mainly in developing } \\
\text { countries. }\end{array}$ & $\begin{array}{l}\text { Three projects have been certified, } \\
\text { five are currently undergoing third- } \\
\text { party validation; over thirty projects } \\
\text { are preparing their project } \\
\text { documentation. }\end{array}$ \\
\hline $\begin{array}{c}\text { Global } \\
\text { Conservation } \\
\text { Standard (GCS) }\end{array}$ & $\begin{array}{l}\text { Currently in its launching phase, } \\
\text { developed by a consultancy } \\
\text { network of scientists and experts } \\
\text { related to the land-use and } \\
\text { forestry sector, on behalf of } \\
\text { Carbon Credited Farming PLC. }\end{array}$ & $\begin{array}{l}\text { Facilitation of the monetization of } \\
\text { conservation assets through the generation of } \\
\text { conservation credit units (CCUs) from carbon } \\
\text { sinks and other environmental services. }\end{array}$ & $\begin{array}{l}\text { GCS is intended for use by } \\
\text { government or private } \\
\text { landowners and license holders } \\
\text { of conservation areas. }\end{array}$ & $\begin{array}{l}\text { Pilot projects are underway in } \\
\text { Indonesia and the Philippines. }\end{array}$ \\
\hline $\begin{array}{l}\text { Plan Vivo } \\
\text { Standards }\end{array}$ & $\begin{array}{l}\text { Originates from a research project } \\
\text { in southern Mexico, initiated in } \\
\text { 1994. Developed by the } \\
\text { Edinburgh Centre for Carbon } \\
\text { Management in collaboration with } \\
\text { El Colegio de la Frontera Sur and } \\
\text { the University of Edinburgh. }\end{array}$ & $\begin{array}{l}\text { Promotion of sustainable livelihoods among } \\
\text { communities, smallholders, and farmers; to } \\
\text { provide ecosystem services and promotion of } \\
\text { the protection and planting of native and } \\
\text { naturalized tree species. }\end{array}$ & $\begin{array}{l}\text { Designed for use by project- } \\
\text { developing organizations for } \\
\text { land-based carbon projects in } \\
\text { developing countries. }\end{array}$ & $\begin{array}{l}\text { Four registered projects; } \\
\text { Two projects in the validation stage. }\end{array}$ \\
\hline SOCIALCARBON & $\begin{array}{l}\text { Developed } 1998 \text { by the Brazilian } \\
\text { non-profit organization Ecologica } \\
\text { Institute originating from a carbon } \\
\text { sequestration project in the } \\
\text { Brazilian state of Tocantins. }\end{array}$ & $\begin{array}{l}\text { Adding value to GHG mitigation projects } \\
\text { through continuous improvement of social, } \\
\text { environmental, and economic performances. }\end{array}$ & $\begin{array}{l}\text { Designed for use by project- } \\
\text { developing organizations for } \\
\text { land-based carbon projects that } \\
\text { operate in developing countries. }\end{array}$ & $\begin{array}{l}\text { No REDD+ projects registered or } \\
\text { under validation. }\end{array}$ \\
\hline
\end{tabular}


Table 1. Cont.

\begin{tabular}{|c|c|c|c|c|}
\hline Standard & Background & Objectives & Applicability & $\begin{array}{l}\text { Certified projects/area by } \\
\text { December } 2010\end{array}$ \\
\hline $\begin{array}{c}\text { International } \\
\text { Standardization } \\
\text { Organization (ISO) } \\
\text { ISO 14064-2:2006 } \\
\text { ISO 14064-3:2006 }\end{array}$ & $\begin{array}{l}\text { ISO is a worldwide federation of } \\
\text { national standards bodies that } \\
\text { designs international standards } \\
\text { after a technical committee for a } \\
\text { specific sector is established } \\
\text { ISO } 14064-2,3: 2006 \text { released } \\
\text { in } 2006 \text {. }\end{array}$ & $\begin{array}{l}\text { Provision of a framework for quantification, } \\
\text { monitoring, and reporting of greenhouse gas } \\
\text { emission reductions or removals on project } \\
\text { level and guidance on validation and } \\
\text { verification of greenhouse gas assertions. }\end{array}$ & $\begin{array}{l}\text { Intended to be used by standard } \\
\text { organizations and project } \\
\text { developing organizations for } \\
\text { providing evidence of credible } \\
\text { and verifiable GHG assertions. }\end{array}$ & $\begin{array}{l}\text { ISO does not certify GHG projects } \\
\text { or issue carbon credits. }\end{array}$ \\
\hline $\begin{array}{l}\text { Voluntary Carbon } \\
\text { Standard (VCS) }\end{array}$ & $\begin{array}{l}\text { Initiated in } 2005 \text { by The Climate } \\
\text { Group, the International Emission } \\
\text { Trading Association, and the } \\
\text { World Economic Forum as a } \\
\text { program for the validation and } \\
\text { verification of voluntary GHG } \\
\text { mitigation projects. }\end{array}$ & $\begin{array}{l}\text { The VCS program seeks to provide a robust } \\
\text { global GHG accounting standard for carbon } \\
\text { offset projects participating in the voluntary } \\
\text { carbon market. }\end{array}$ & $\begin{array}{l}\text { Intended to be used by project } \\
\text { developing organizations of } \\
\text { emission reduction projects. }\end{array}$ & $\begin{array}{l}\text { Four REDD+ methodologies have } \\
\text { been approved. Currently, several } \\
\text { subnational REDD+ projects are in } \\
\text { the pipeline, and one single A/R } \\
\text { project has been registered. }\end{array}$ \\
\hline
\end{tabular}

Sources: [15-30]. 


\subsubsection{Protection of Biodiversity}

Under the biodiversity criterion, we assess whether standards apply the High Conservation Value (HCV) approach [31], whether they require the protection of rare and endangered species, and whether the regulation of the schemes reflects the local population's social and cultural values of biodiversity. The criterion is particularly pertinent to the biodiversity safeguards requirement. We assess whether standards apply the HCV approach, whether standards require the protection of rare and endangered species, and whether the regulation of the schemes reflects the local population's social and cultural values of biodiversity.

\subsubsection{Measurement and Assessment of GHG Benefits}

REDD+ projects and/or programs must ensure that GHG benefits are real, measurable, reportable verifiable, and permanently secured [32]. Thus, standards schemes that establish a regulatory framework for GHG accounting are scrutinized towards their regulation on certification and issuance of GHG benefits, their compliance with scientific judgment and their permanence assurance mechanisms.

\subsubsection{Monitoring and Reporting}

Monitoring and reporting form a necessary basis for independent verification of the emission reduction benefits as well as net positive social and environmental impacts of REDD+ activities. Therefore, we analyze the standards' monitoring and reporting requirements, their regulations on the establishment of monitoring plans, the length of monitoring and reporting cycles over the project lifetime (periodicity), and the principles of monitoring and reporting.

\subsubsection{Certification Procedures}

To achieve credibility and to ensure that projects and/or programs comply with the respective principles and criteria, the various standards schemes adopt different certification procedures designed to credibly validate and verify that such compliance occurs. The standards are assessed against three criteria: the involvement of accredited third-party auditors, the periodicity and minimum time intervals of verification, and culturally appropriate stakeholder consultations during the certification process.

\subsection{Evaluation}

In order to draw conclusions on the relevance of the standards schemes for REDD+, we conducted an evaluation of standards comprehensiveness and rigor with respect to the six criteria categories. The evaluation of the standards in chapter four is based on the comparative assessment of standards' principles and criteria as described in Section 2.2. To implement this, we developed a relative ordinal ranking system that assigns a value between " 0 " and " 2 " to each of the six criteria. The assignment of a grade to each criterion indicates the level of standards comprehensiveness relative to the other standards being evaluated; we did not use a specific benchmark. Thus, a grade of " 0 " indicates that the standard does not provide any regulation on the respective assessment criteria, whereas a " 2 " indicates that the assessment criteria is addressed comprehensively compared to other standards. The value " 1 " 
indicates that the standards only partly provide guidance on the assessment criteria relative to those that received a " 2 ". This relative ranking system allows us to evaluate the complementarity of the different standards for relative completeness within each criterion and globally across the different criteria. As there is no internationally accepted benchmark for the assessment of standards comprehensiveness and rigor, our ranking systems serves as a basis for further discussion and seeks to provide indications on the comprehensiveness of standards, and their relevance and applicability for REDD+ projects or initiatives. It is important to note that there is normally a trade-off between the comprehensiveness of standards and their cost-effective applicability as comprehensive and rigorous standards require more efforts and cost in order to comply with these. Thus, if standards are too complex, restrictive and too costly to apply, there will be pressure to design more flexible schemes [12].

\section{Comparative Analysis of the Standards' Principles and Criteria}

REDD+ is not only a GHG reduction mechanism, but - if properly designed - REDD+ activities have the potential to deliver significant additional benefits such as poverty alleviation, sustainable forestry production management, and the protection of biodiversity [13]. However, if standards are not rigorous enough and do not set requirements on social and environmental safeguards, there are risks of misusing potential REDD+ funds. This section therefore provides an overview of the standards' principles and criteria with regards to the described four substantive and the two procedural criteria.

\subsection{Poverty Alleviation}

All standards, except the VCS and ISO, have established regulatory frameworks that consider rights and livelihoods of local stakeholders affected by the projects or programs implemented and certified. As illustrated in Table 2, all of these standards require compliance with national laws, programs, or policies, and require that land tenure and property rights over forest resources are clarified (or dispute resolving mechanisms are in place), that customary rights are respected, and that stakeholders participate and are consulted in an appropriate manner. Moreover, these standards require that projects or programs facilitate capacity building such as knowledge transfer and employment generation. With respect to a benefit sharing mechanism FSC and PEFC do not provide as strong guidance on benefit sharing as the remaining standards. Furthermore, only CCB and the GCS require assessing projects' impacts inside as well as outside the project area, while the remaining standards require assessment only within the project boundaries. Thus, CCB and GCS provide the most comprehensive guidance to evaluating poverty alleviation dimensions of a project. 
Table 2. Standards' poverty alleviation approaches.

\begin{tabular}{|c|c|c|c|c|c|c|}
\hline Standard & $\begin{array}{c}\text { Legal } \\
\text { compliance } \\
\text { to laws and } \\
\text { rights }\end{array}$ & $\begin{array}{c}\text { Stakeholder } \\
\text { participation } \\
\text { and } \\
\text { consultation }\end{array}$ & $\begin{array}{c}\text { Conflict } \\
\text { resolution } \\
\text { mechanisms }\end{array}$ & $\begin{array}{l}\text { Assessment of } \\
\text { impacts } \\
\text { outside the } \\
\text { project area }\end{array}$ & $\begin{array}{l}\text { Requirement } \\
\text { to evidence } \\
\text { capacity } \\
\text { building }\end{array}$ & $\begin{array}{c}\text { Equitable } \\
\text { benefit } \\
\text { sharing }\end{array}$ \\
\hline FSC & $\sqrt{ }$ & $\checkmark$ & $\checkmark$ & & $\checkmark$ & 0 \\
\hline PEFC & $\sqrt{ }$ & $\sqrt{ }$ & $\sqrt{ }$ & Not applicable & $\sqrt{ }$ & 0 \\
\hline CCB & $\checkmark$ & $\checkmark$ & $\checkmark$ & $\checkmark$ & $\sqrt{ }$ & $\checkmark$ \\
\hline CCBA S\&E & $\checkmark$ & $\checkmark$ & $\checkmark$ & Not applicable & $\checkmark$ & $\checkmark$ \\
\hline CarbonFix & $\checkmark$ & $\checkmark$ & $\checkmark$ & & $\checkmark$ & 0 \\
\hline GCS & $\sqrt{ }$ & $\checkmark$ & $\checkmark$ & $\checkmark$ & $\checkmark$ & $\checkmark$ \\
\hline Plan Vivo & $\checkmark$ & $\checkmark$ & $\checkmark$ & & $\checkmark$ & $\checkmark$ \\
\hline $\begin{array}{l}\text { SOCIAL } \\
\text { CARBON }\end{array}$ & $\checkmark$ & $\checkmark$ & $\checkmark$ & & $\checkmark$ & $\checkmark$ \\
\hline
\end{tabular}

\subsection{Sustainable Management of Forests (SMF)}

Except for VCS and ISO, all standards require the compliance with principles and criteria related to SMF as described in section 2.2 (Table 3).

Table 3. Standards' sustainable management of forests approaches.

\begin{tabular}{|c|c|c|c|c|}
\hline Standard & $\begin{array}{c}\text { Elaborative } \\
\text { guidance on design } \\
\text { of forest } \\
\text { management plans }\end{array}$ & $\begin{array}{l}\text { Maintenance and } \\
\text { protection of } \\
\text { ecosystem } \\
\text { services }\end{array}$ & $\begin{array}{c}\text { Avoidance of } \\
\text { converting } \\
\text { natural forest to } \\
\text { other land uses }\end{array}$ & $\begin{array}{l}\text { Integration of REDD+ } \\
\text { activities into overall } \\
\text { land use planning and } \\
\text { national forest policies }\end{array}$ \\
\hline FSC & $\checkmark$ & $\checkmark$ & $\checkmark$ & \\
\hline PEFC & 0 & $\checkmark$ & $\sqrt{ }$ & $\checkmark$ \\
\hline CCB & & $\checkmark$ & $\sqrt{ }$ & \\
\hline CCBA S\&E & $\sqrt{ }$ & $\sqrt{ }$ & $\sqrt{ }$ & $\sqrt{ }$ \\
\hline CarbonFix & $\checkmark$ & $\checkmark$ & $\sqrt{ }$ & \\
\hline GCS & 0 & $\checkmark$ & $\checkmark$ & $\checkmark$ \\
\hline Plan Vivo & 0 & $\checkmark$ & $\checkmark$ & \\
\hline SOCIALCARBON & & $\sqrt{ }$ & $\sqrt{ }$ & \\
\hline
\end{tabular}

Sources: [14,15,19-21,24,25,27,29,33].

With respect to the principles and criteria on SMF as illustrated in Table 3, the FSC and PEFC have similar approaches. However, while the FSC provide a global framework on forest management applicable to boreal, temperate and tropical regions, the PEFC is an umbrella certification organization facilitating the development of country-specific standards [12,34]. Therefore, in this comparison only the PEFC Council minimum requirements checklist is considered and not the national standards. 
Similar to the FSC, CarbonFix has set dedicated requirements on SMF while CCB and SOCIALCARBON did not set standards on SMF. The GCS and CCBA S\&E are standards that focus on the integration of national forest policies into the broader national land use management plans.

\subsection{Biodiversity Conservation}

High Conservation Value (HCV) is the most common concept in the standards for addressing the protection of biodiversity. The concept helps identify and manage the environmental or social values of forests and other ecosystems where these values are assumed to be of outstanding significance [31]. In addition, all critical ecosystem services such as water, fire control, and provisioning services (e.g., food, fuel, fodder, medicines, building materials), as well as other critical areas of cultural, ecological, economic or religious importance, must be protected [15,20].

The FSC, CCB Standards, GCS, and CCBA REDD+ S\&E Standards require project developers to apply the HCV concept. The CCBA REDD+ S\&E Standards also require the inclusion of all biodiversity and ecosystem service values identified in existing "national biodiversity strategy and action plans", and to conduct gap analyses supporting the Convention on Biological Diversity, and other conservation planning approaches [29]. The CarbonFix Standard requires project developers to establish and manage a nature conservation area of at least $10 \%$ of the entire project area, in order to protect and manage fauna and flora and to maintain or improve the ecological natural ecosystem services and to integrate the project into the natural landscape [24]. The PECF's "minimum requirements checklist" obliges projects to minimize impacts on forest structures and biodiversity, and demands that national standard-setting processes address natural regeneration of forests [33]. Among the standards, it is perhaps not surprising that the CCB standards provide the most comprehensive coverage of biodiversity values since that is one of the principal aims of the standard design (Table 4).

Table 4. Standard's biodiversity conservation approaches.

\begin{tabular}{|c|c|c|c|}
\hline Standard & $\begin{array}{c}\text { Conservation of rare and } \\
\text { endangered species }\end{array}$ & $\begin{array}{l}\text { Consideration of social and } \\
\text { cultural values of biodiversity }\end{array}$ & $\begin{array}{l}\text { Application of the } \\
\text { HCV framework }\end{array}$ \\
\hline FSC & $\checkmark$ & $\checkmark$ & $\checkmark$ \\
\hline PEFC & $\sqrt{ }$ & $\sqrt{ }$ & 0 \\
\hline CCB & $\sqrt{ }$ & $\sqrt{ }$ & $\sqrt{ }$ \\
\hline CCBA S\&E & $\checkmark$ & $\checkmark$ & $\sqrt{ }$ \\
\hline CarbonFix & $\sqrt{ }$ & $\sqrt{ }$ & 0 \\
\hline GCS & $\sqrt{ }$ & $\checkmark$ & $\checkmark$ \\
\hline Plan Vivo & $\checkmark$ & $\checkmark$ & \\
\hline SOCIALCARBON & $\sqrt{ }$ & 0 & \\
\hline
\end{tabular}

\subsection{Greenhouse Gas Accounting}

Only six of the ten standards provide guidance on GHG measurement, monitoring, and reporting (Table 5); and only three of these certify and issue Voluntary/Verified Emission Reduction (VERs). 
Table 5. Standards' GHG accounting approaches.

\begin{tabular}{|c|c|c|c|}
\hline Standard & $\begin{array}{c}\text { Regulation on GHG } \\
\text { accounting }\end{array}$ & $\begin{array}{l}\text { Certification and } \\
\text { issuance of emission } \\
\text { reductions }\end{array}$ & $\begin{array}{c}\text { Permanence } \\
\text { assurance based on } \\
\text { buffer accounts }\end{array}$ \\
\hline \multicolumn{4}{|l|}{ FSC } \\
\hline \multicolumn{4}{|l|}{ PEFC } \\
\hline $\mathrm{CCB}$ & $\sqrt{ }$ & & \\
\hline \multicolumn{4}{|l|}{ CCBA S\&E } \\
\hline CarbonFix & $\checkmark$ & $\checkmark$ & $\sqrt{ }$ \\
\hline GCS & $\sqrt{ }$ & 0 & \\
\hline Plan Vivo & $\checkmark$ & $\sqrt{ }$ & $\sqrt{ }$ \\
\hline \multicolumn{4}{|l|}{ SOCIALCARBON } \\
\hline ISO & $\sqrt{ }$ & & \\
\hline VCS & $\checkmark$ & $\checkmark$ & $\checkmark$ \\
\hline
\end{tabular}

Source: [15-17,19,21, 23-27,30,33,35,37-39].

These standards are the CarbonFix Standard, Plan Vivo Standards, and VCS, whereby GCS certifies and issues conservation credit units (CCUs), which represent a new approach of valuing and monetizing conservation of ecosystems. ISO 14064:2006 Parts 2 and 3 set out general principles on GHG quantification and MRV of project-based GHG emission reductions and carbon removals. ISO 14064:2006 Part 2 includes the six crucial principles for GHG accounting requiring that emission reductions or removals are relevant, complete, consistent, accurate and transparent, and that they are conservatively estimated [16]. The VCS AFOLU framework used these principles to adapt its methodological guidance on GHG quantification and monitoring; it also set additional guidance on the accounting of GHG benefits from four land use categories. For subnational REDD+ projects, three types of REDD+ activities are eligible: avoiding planned deforestation (APD), avoiding unplanned frontier deforestation and degradation (AUFDD), and avoiding unplanned mosaic deforestation and degradation (AUMDD). For the quantification of GHG benefits occurring from project activities, project developers must either use the tools and modules of the $\mathrm{A} / \mathrm{R} \mathrm{CDM}$, or submit new methodologies based on the IPCC Guidelines on Agriculture, Forestry and Other Land Use (GL AFOLU) 2006 [23]; new methodologies are subject to an intensive approval process by two independent third-party auditors [22]. In addition, project developers must also implement a risk assessment based on the "tool for AFOLU non-permanence risk analysis and buffer determination" and withhold a certain percentage of carbon credits in a VCS "AFOLU pooled buffer account" [35]. The CCB Standards require REDD+ project developers to use the IPCC 2006 GL AFOLU to provide evidence of projects' climatic benefits, but does not issues carbon credits and requires the application of GHG accounting standards in order to participate in the voluntary carbon market [20]. The CarbonFix Standard developed a single simplified GHG accounting methodology for A/R projects based on the IPCC GL AFOLU 2006 and A/R CDM methodologies [30,36]. The standard provides a practically applicable methodology for A/R projects that can be regarded as being among the "plus" activities in REDD. CarbonFix requires withholding 30\% of the issued credits in a buffer account. 
Under the Plan Vivo Standards framework, project coordinators, in cooperation with technical experts, must develop an appropriate, project-specific carbon accounting methodology. External experts determine the risk of non-permanence and the risk percentage (minimum 10\%). Beyond that limit, a project is prohibited from selling credits [21]. In contrast, the GCS's invention of CCUs creates a new currency in the voluntary market, as it is directed to existing carbon stocks and not carbon stock changes as under all other GHG programs.

\subsection{Monitoring and Reporting}

Generally, monitoring serves as a basis for third-party verification of the actual achievements of REDD+ projects or programs. The standards differ in their monitoring approaches with respect to the periodicity and the actual content of the monitored data. Under the FSC monitoring must be executed based on the forest management plans at appropriate scales and intensities, and the exercise serves as a tool to periodically adapt and revise the management plans as well as to conduct periodic third-party audits [15]. By contrast, the PEFC does not provide guidance on the monitoring requirements, as these are to be determined through the national standard-setting processes [18]. Within the CCB Standards framework, a monitoring plan must be completed no more than 12 months after the initial validation of a project, setting out how the climate, community, and biodiversity achievements will be monitored [20]. The CCBA REDD+ S\&E Standards adopt flexible country-specific options for MRV with the aim of transparently and accountably balancing participation and ownership by stakeholders [29]. The GCS and Plan Vivo require-and the SOCIALCARBON Standard recommends - annual monitoring that serves as a basis for adapting technical management documents, which must be submitted for acceptance to the respective standard bodies to prove project performance. Monitoring within the GCS framework must be conducted for at least 30 years after the project starts, which is the minimum duration of the Conservation Agreement, while the minimum monitoring duration under Plan Vivo and SOCIALCARBON is not pre-determined [21,27,30]. Within the CarbonFix framework, project developers must follow an inventory guideline for $\mathrm{A} / \mathrm{R}$ projects, which serves as a basis for monitoring of GHG benefits; the socioeconomic and environmental aspects and are monitored by continuously meeting the standard's criteria through continuous adaptation of the project design document subject to periodic third-party verification. Projects must be monitored for at least 30 years [24]. With respect to GHG monitoring and reporting, the VCS requirements comply with the general monitoring principles of ISO 14064-2:2006. Thereby project developers must develop robust monitoring protocols that are based on the IPCC GL, the A/R CDM methodologies, or other REDD-specific methodologies approved under the VCS or UNFCCC that may become available in future $[22,38]$.

\subsection{Certification Procedures}

In this section we describe the major differences between the standards and illustrate in Table 6 what standards certify, their verification and monitoring periodicities and their requirements with respect to the accreditation of third parties that conduct independent certification audits. 
Table 6. Standards' certification modalities.

\begin{tabular}{|c|c|c|c|}
\hline Standard & Certification type & $\begin{array}{l}\text { Verification and } \\
\text { monitoring } \\
\text { periodicity }\end{array}$ & Eligible third-party auditors \\
\hline CCB Standards & $\begin{array}{l}\text { Net positive climate, social } \\
\text { and environmental project } \\
\text { performance }\end{array}$ & Every five years & $\begin{array}{ll}- & \text { CDM DOEs scope } 14 \\
- & \text { FSC certification bodies } \\
- & \text { ISO 14065:2007 accredited } \\
& \text { bodies }\end{array}$ \\
\hline FSC & SMF and chain of custody & $\begin{array}{l}\text { Every five years }+ \\
\text { annual surveillance } \\
\text { audits }\end{array}$ & $\begin{array}{l}\text { FSC Certification bodies } \\
\text { accredited by Accredited } \\
\text { Services International (ASI) }\end{array}$ \\
\hline PEFC & SMF and chain of custody & $\begin{array}{l}\text { Every three years + } \\
\text { annual surveillance } \\
\text { audits }\end{array}$ & $\begin{array}{l}\text { Members of the International } \\
\text { Accreditation Forum compliant } \\
\text { with ISO }\end{array}$ \\
\hline CarbonFix & $\begin{array}{l}\text { Net positive GHG benefits } \\
\text { certification, social and } \\
\text { environmental project } \\
\text { performance }\end{array}$ & Every five years & $\begin{array}{l}\text { DOEs for } \mathrm{A} / \mathrm{R} \mathrm{CDM} \\
\text { FSC certification bodies } \\
\text { (accredited for SMF) }\end{array}$ \\
\hline GCS & $\begin{array}{l}\text { Conservation benefits and } \\
\text { net positive social and } \\
\text { environmental performance } \\
\text { of conserved areas }\end{array}$ & Annually & Under development \\
\hline Plan Vivo & $\begin{array}{l}\text { Net positive GHG benefits } \\
\text { certification, social and } \\
\text { environmental project } \\
\text { performance }\end{array}$ & $\begin{array}{l}\text { Annual revision by } \\
\text { Plan Vivo and third- } \\
\text { party verification at } \\
\text { least every five years }\end{array}$ & $\begin{array}{l}\text { - } \text { CDM DOEs scope } 14 \\
\text { - FSC certification bodies } \\
\text { - ISO } 14064 \text { accredited bodies } \\
\text { - Accredited certification bodies by the } \\
\text { California Climate Action Reserve }\end{array}$ \\
\hline SOCIALCARBON & $\begin{array}{l}\text { Net positive socioeconomic } \\
\text { performance }\end{array}$ & Flexible & CDM DOEs \\
\hline VCS & Net positive GHG benefits & $\begin{array}{l}\text { At least every five } \\
\text { years }\end{array}$ & $\begin{array}{ll}\text { - } & \text { DOEs sectoral scope } 14 \\
\text { - } & \text { Accredited Independent JI Entities } \\
\text { - } & \text { Approved Certification Bodies of } \\
\text { the Climate Action Reserve } \\
\text { (accredited under ISO 14065:2007) } \\
\text { - } & \text { VCS Temporary Accreditation } \\
& \text { Program bodies }\end{array}$ \\
\hline
\end{tabular}

Sources: [15,20-24,27,29,30,37,39-43].

Of the 10 standards, only the CCBA REDD+ S\&E Standards do not have prescribed third-party certification procedures [29]. The ISO 14064-3:2006 guidelines on "validation and verification of GHG assertions" require validation/verification bodies (VBs) to demonstrate professional competence, be independent, be free of conflicts of interest, and meet the requirements of the GHG programs against which the VB validates and verifies projects [17]. Once an organization that meets these criteria has been chosen as a VB, the validation and verification assessment follows procedures outlined in the ISO guidelines. 
Based on the project design documents (PDDs), monitoring plans and field visits, CCBA projects must be initially validated by independent third-party auditors and subsequently verified against the standards at least every five years.

Within the FSC framework, certification is conducted by certification bodies (CBs), which are accredited by Accreditation Services International (ASI). In addition, CBs must also carry out annual surveillance audits in order to verify continuous compliance with FSC requirements [40]. Similarly, the PEFC requires that after the independent third parties assessment and if forest management meets all PEFC certification requirements, a forest management and/or a CoC certificate is issued, valid for three years, which must be renewed after expiry. Also annual surveillance audits are obligatory to confirm compliance with the PEFC's forest management and/or CoC requirements [41]. Eligible CBs must be members of the International Accreditation Forum (IAF) and comply with relevant ISO guides and requirements [37]. However, certification procedures may differ depending on the country-specific PEFC-endorsed national certification systems. The CarbonFix Standard, the GCS, and Plan Vivo have developed an innovative approach to reduce the significant transaction costs associated with third-party validation and verification, by which standard-specific technical bodies conduct pre-assessments before the actual third-party assessments. This helps to reduce costs for third party certification as the pre-assessments serve as preparatory activity in order to prove the likely compliance with all standards' requirements $[21,24]$. Projects under the SOCIALCARBON Standard are validated by third parties often together with a GHG accounting standard after the submission of the PDD and monitoring reports [27]. For project certification and the issuance of voluntary carbon units (VCUs) under the VCS, project developers must undergo validation and verification by two independent third-party auditors (compliant with the requirements of ISO 14064:2006 Part 3). The project developer selects one auditor and the VCS association selects the other. Subsequently, verification should be conducted at least every five years, but is not obligatory. In case new methodologies are proposed the acceptance of these must be assessed by two independent third-party auditors through a "double approval process [22].

\section{Standards' Evaluation}

As our comparative analysis of 10 standards schemes and the project examples have shown, there is a wide range of approaches and scopes for certifying REDD+ projects and programs. The voluntary nature of these standards on the one hand provides project developers the freedom to select appropriate standards for their project and facilitates their innovative character, allowing them to serve as an important test bed to ensure projects deliver on SMF, deliver biodiversity conservation, contribute to poverty alleviation and provide GHG benefits, without intruding on countries' sovereignty. On the other hand, the requirement to select among standards can be also regarded as a significant constraint in the voluntary carbon market, as the array of standards comprises a level of market non-transparency, inefficiency and uncertainty among market actors. The result is that the standards compete for market credibility and support [12,34]. For the selection of appropriate standards for a REDD+ project or program, the objectives and the scale of the activities are an important element in the decision. Our review found that no single standard fully covers all essential aspects of REDD+ activities and that the combination of certification schemes would be required in order to satisfy all six sets of criteria for 
REDD+ certification. Therefore, the following sections briefly evaluate the key innovations of the standard schemes, provide recommendations on potential combinations of the ten standards and graphically illustrate standards comprehensiveness and rigor with respect to the four substantive criteria and the two procedural criteria.

\subsection{CCBA REDD+ S\&E Standards}

The REDD+ S\&E Standards can be described as a governance standard that is applicable to governments and regions seeking to design and develop institutional and political REDD+ frameworks in a participatory manner. Thus, strengthening community and Indigenous Peoples' rights and improving livelihoods of people in the project area are essential when applying the standard, and the standard scores high in this area (Figure 1). The standards are designed to lead to the alleviation of poverty through the involvement of all relevant stakeholders, the conservation of biodiversity, and the development of SMF policies on the national or regional level. However, as the CCBA does not set regulations on third-party verification, REDD+ activities' compliance with the standards' principles and criteria is not standardized, and thus compliance is difficult to assess. The effectiveness of the standards can be enhanced by combining them with FSC, PEFC, GCS and/or VCS certification. The FSC and PEFC could be applied to secure SMF practices; the GCS is applicable for conservation projects that facilitates the monetization of conserved ecosystems, and the VCS for the development of REDD projects on a subnational scale with potential to integrate subnational MRV into national MRV systems.

Figure 1. Evaluation of CCBA REDD+ S\&E.

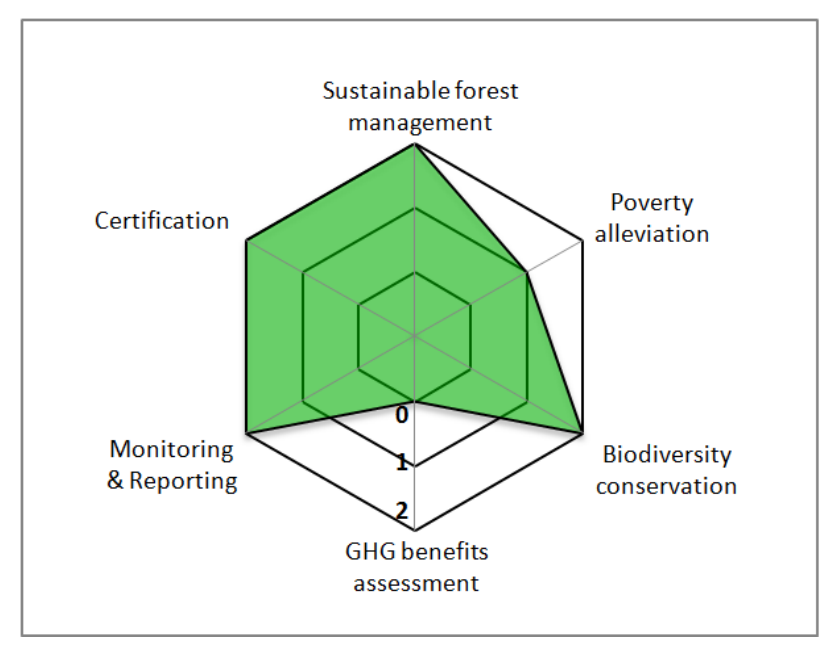

\subsection{Forest Stewardship Council (FSC)}

FSC is the second largest certification scheme after PEFC that has valuable experiences that could serve as an important mechanism to promote and implement SMF and the development of international REDD+ rules [12]. The standard is dedicated to the promotion of best practices in SMF through long-term forest management planning, which includes the conservation of biodiversity through the HCV concept and sharing of benefits from forest management. The standard scores high in these areas (Figure 2). In addition, its rigorous certification processes and accreditation system for 
third-party auditors guarantee independent and objective verification of SMF practices. The standard is applicable at the project, regional, and national levels. At the national level, the FSC can be combined with CCBA's REDD+ S\&E Standard to ensure SMF combined with the improvement of national REDD+ policies. To generate carbon credits at the project level, the CarbonFix Standard can be used for $\mathrm{A} / \mathrm{R}$ activities or the VCS can be used for A/R, REDD+, and/or Improved Forest Management (IFM) projects that deliver net GHG benefits. Projects certified under the FSC that include conservation areas can also apply the GCS, as it provides a mechanism to value and monetize carbon stocks on conserved areas.

Figure 2. Summary of Forest Stewardship Council.

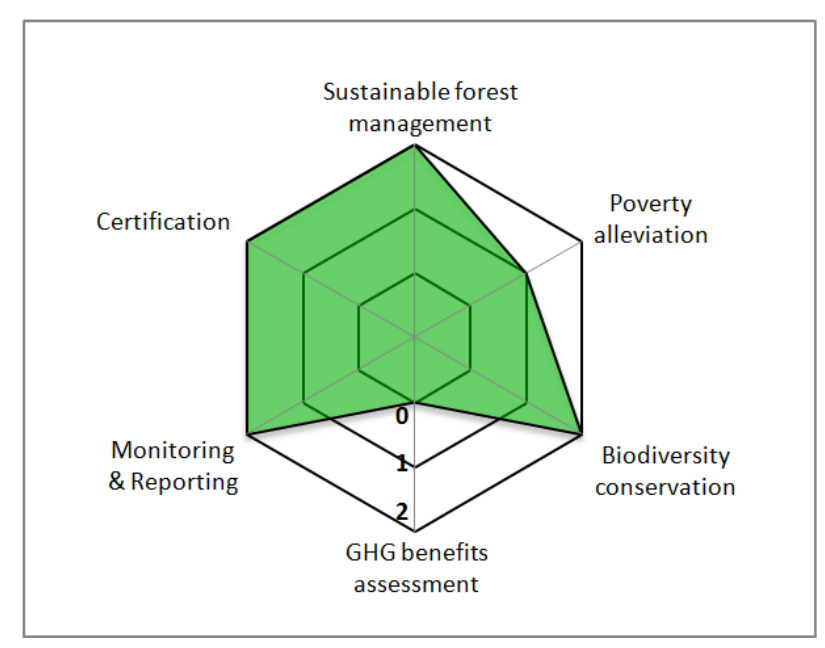

\subsection{Programme for the Endorsement of Forest Certification (PEFC)}

The PEFC framework is a flexible forest management standard that sets a framework for the development of regional or national activities. The participatory standard-setting process ensures that stakeholders adapt the standards to regional or national conditions, thus ensuring national sovereignty. National PEFC standards can vary significantly in social and environmental rigor [12], thus the quality of the each standard national must be assessed based on the PEFC guidelines. PEFC features rigorous certification procedures with the accreditation system based on third-party auditors and periodic independent and objective verification of both forest management and chain of custody and scores high in these areas (Figure 3). The PEFC standard is applicable to national or regional scales as well as to large-scale projects. As with the FSC at the project level, the PEFC can be combined with the CarbonFix Standard for A/R projects or the VCS for different REDD+-related forestry project types in order to generate carbon credits. Furthermore, the GCS can be used in conservation areas in combination with sustainable forest production certified under the PEFC. On a national scale, it could be combined with the CCBA REDD+ S\&E Standards to facilitate the development of national forest policies. 
Figure 3. Summary of Programme for the Endorsement of Forest Certification (PEFC).

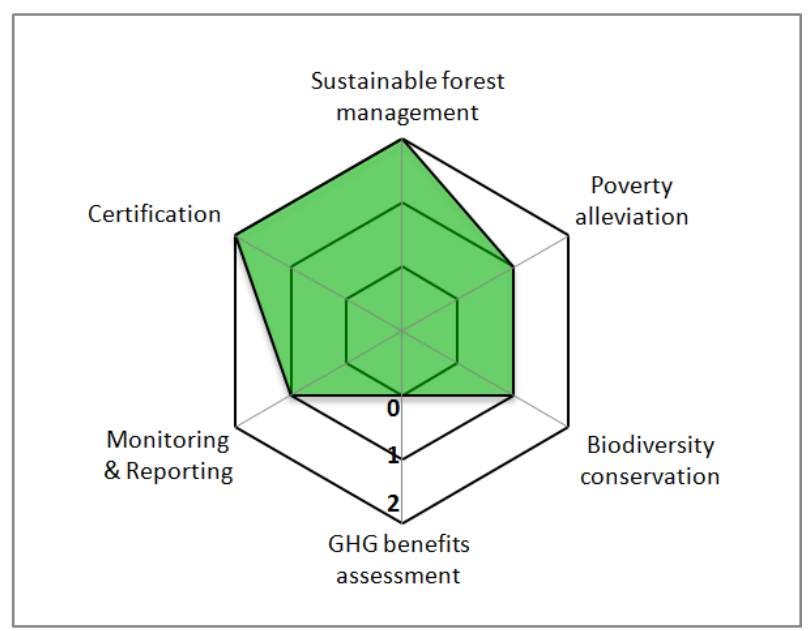

\subsection{Climate, Community and Biodiversity Standards (CCB)}

The CCB Standards aim to ensure that forest carbon projects are designed and implemented in a participatory manner, with all relevant stakeholders involved in the project design, and that such projects meet the criteria on climate additionality, community effects, and biodiversity (Figure 4). The project design, independent third-party validation, and periodic certification ensure that certified activities contribute to the alleviation of poverty and the protection of biodiversity both inside and outside the project boundaries. The standard is applicable for large-scale REDD+ projects, but it must be combined with other GHG accounting standards such as the CarbonFix Standard or the VCS if carbon offset credits are to be generated. If projects that are designed according to the CCB standards include forest production, either FSC or PEFC would be required to certify SMF practices.

Figure 4. Summary of Climate, Community and Biodiversity Standards.

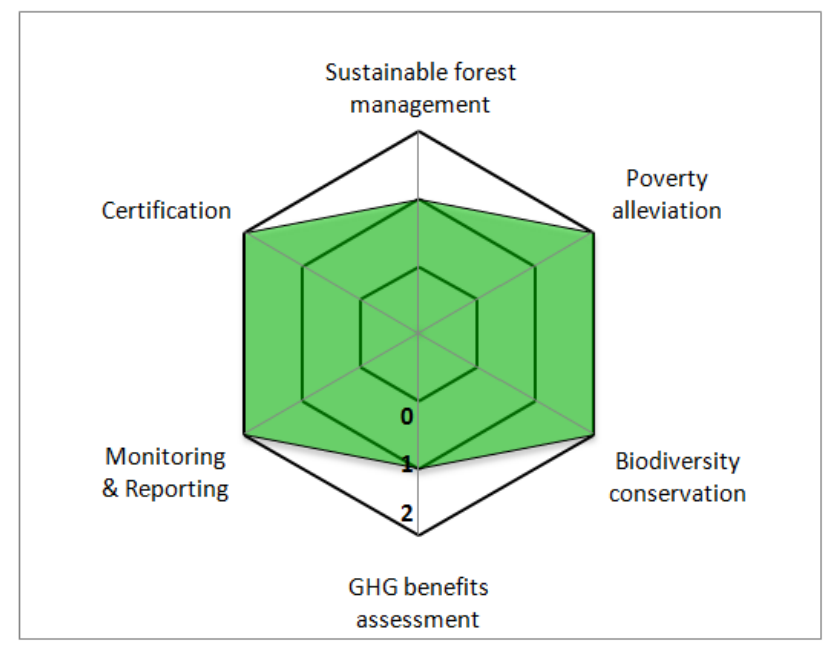

\subsection{SOCIALCARBON Standard}

Similarly to the CCB Standards, the SOCIALCARBON Standard requires projects to be designed and managed in a sustainable manner that promote positive socioeconomic development of communities and 
indigenous peoples (Figure 5). Sustainability is determined by evaluation of six resources: natural, financial, human, social, carbon, and biodiversity. With respect to these six resources, projects must contribute to the alleviation of poverty and the promotion of sustainable development. To account for GHG benefits and generate carbon offset credits, carbon accounting standards would have to be applied in addition to the SOCIALCARBON standard. Under such circumstances the VCS or the CarbonFix Standard should be integrated into the certification procedure, depending on the project type.

Figure 5. Summary of SOCIALCARBON Standard.

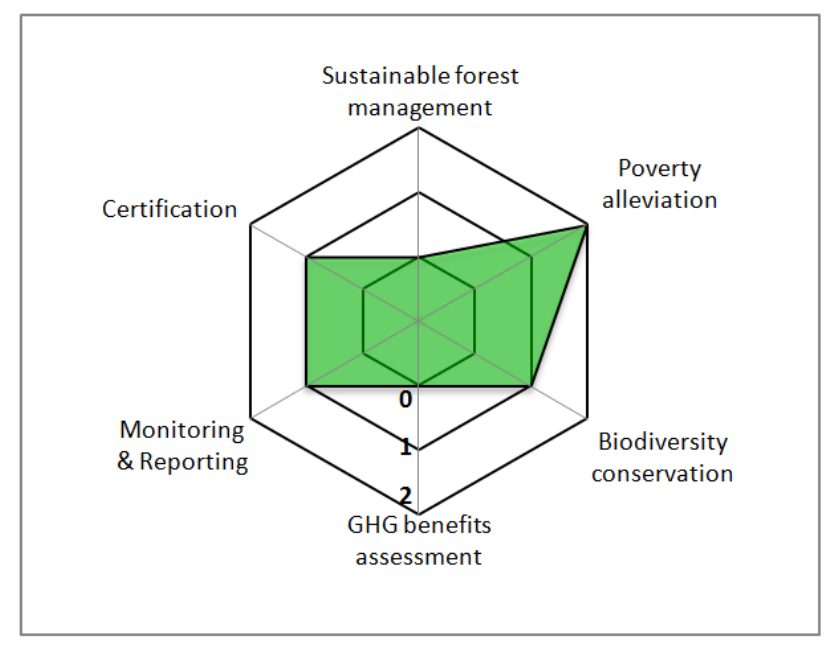

\subsection{CarbonFix Standard}

According to UNFCCC definitions [44], the CarbonFix Standard (CFS) is applicable only to A/R projects, but this standard may be applied to REDD+ projects with a significant work program on forest rehabilitation or activities aimed at increasing $\mathrm{C}$ stocks in existing forests. The standard provides a practical approach that includes a comprehensive framework for designing and implementing $A / R$ projects promoting SMF and forest conservation and implement rigorous monitoring and verification of net carbon stock changes based on IPCC principles (Figure 6).

Figure 6. Summary of CarbonFix Standard.




The standard requires stakeholder participation to be enhanced and that $\mathrm{A} / \mathrm{R}$ activities benefit the local population. It is applicable to both small and large-scale projects. The standard can be combined with the FSC or the PEFC, in order to achieve more credibility in SMF. The CFS provides simplified certification procedures if there will be joint certification with CCB or FSC. In order to achieve greater poverty alleviation and biodiversity conservation benefits, inside and outside the project area, certification with $\mathrm{CCB}$ or SOCIALCARBON standards can be added. Also, combined CCB certification is simplified under the CarbonFix framework. Furthermore, GCS-certified projects can apply for CarbonFix Standard certification if A/R activities occur in the commercial zone around the conservation area (see below).

\subsection{Global Conservation Standard}

The Global Conservation Standard (GCS) is a new standard that seeks to monetize conservation activities based on existing carbon stocks within what the standard calls the "Conservation Area". As the standards is currently under development, its efficacy and innovative potential still need to be proven by certifying conservation projects or programs. The GCS promotes the design and implementation of conservation projects by requiring the development of long-term sustainable conservation management plans. Projects must generate socials and environmental benefits; thus the standard scores highly for poverty alleviation and biodiversity conservation (Figure 7). The income from the sale of so-called Conservation Credit Units (CCUs) are reinvested into commercial forestry and agriculture practices in so called "Commercial Zones", areas surrounding the conservation areas. These zones are set up in order to reduce economic pressure on the conservation zone. The standard is applicable for any landscapes size, as long as the layout includes a Conservation Area and a Commercial Zone. For the generation of offset credits, additional carbon accounting standards at the project level have to be applied, such as the CFS or the VCS. The GCS explicitly encourages sustainable management practices and certification by another standard if commercial production forestry is implemented outside the conservation area.

Figure 7. Summary of Global Conservation Standard.






\subsection{Plan Vivo Standards}

The Plan Vivo Standard is a grass-roots standard that promotes a sustainable development process with smallholders and poor communities in developing countries by adopting long-term land use plans and capacity building. The standard scores highly for its evaluation of poverty and GHG benefits and for its approach to monitoring and reporting (Figure 8). It requires creating partnerships with other technically capable organizations that build capacities, to execute management, and to develop project-specific carbon accounting methodologies. The standard is applicable for smaller projects with options to expand if the projects prove successful in motivating more smallholders to participate. The Plan Vivo Standard is a comprehensive stand-alone standard; its grass-roots approach makes combinations with other standards difficult, thus Plan Vivo projects are normally not combined with any other certification schemes.

Figure 8. Summary of Plan Vivo Standards.

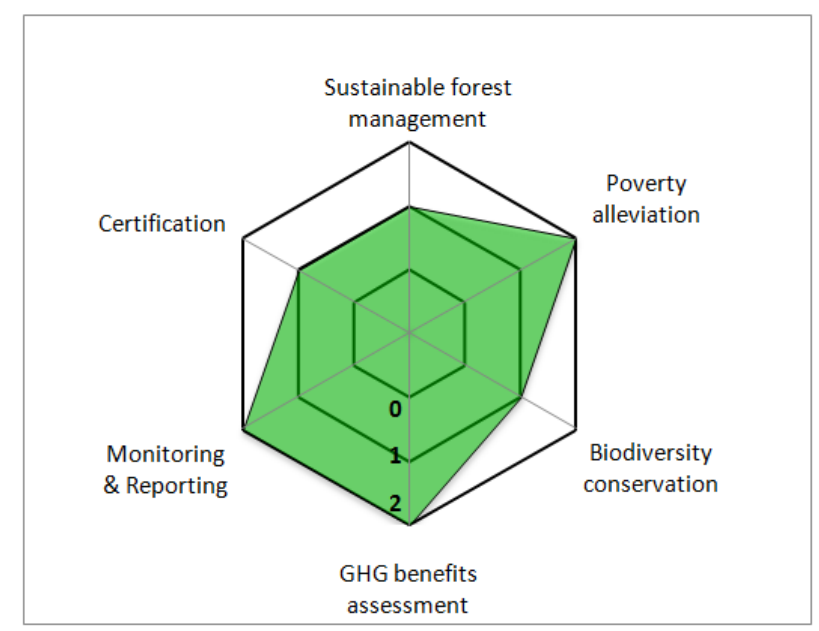

\subsection{ISO 14064:2006 Parts 2 and 3}

ISO sets out general principles on the quantification and MRV of GHG benefits at the project scale. The standards' principles help ensure real, measurable, and verifiable carbon credits. The framework provides a general benchmark on conservative and comprehensive GHG accounting and should be applied by standard-setting organizations as a guiding benchmark to account for GHG benefits. It has strong coverage of monitoring and reporting aspects and of certification of GHG benefits (Figure 9). The application of the standard on its own does not allow the issuance of carbon credits, as ISO does not certify projects. 
Figure 9. Summary of ISO 14064:2006: Parts 2 and 3.

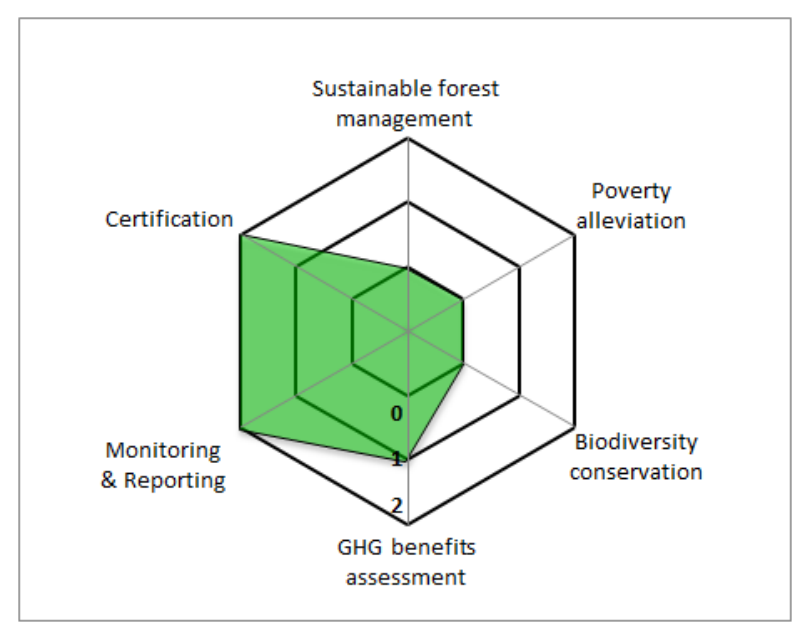

\subsection{Voluntary Carbon Standard (VCS)}

The VCS AFOLU program is a pure GHG accounting standard for all land-based project types based on ISO14064. It does not cover the other dimensions evaluated here (Figure 10). The standard has rigorous MRV requirements for accounting and generating real, measurable, and verifiable carbon credits for the voluntary carbon market that have to comply with IPCC principles. The VCS framework facilitates the development of new project-based methodologies for REDD+ projects at the subnational scale. The development of new methodologies and the use of existing ones provide important capacity-building and learning opportunities at the subnational scale to monitor, report, and verify GHG benefits. This institutional learning can be incorporated into national REDD+ MRV systems. To ensure that REDD+ projects contribute to poverty alleviation, SMF and protection of biodiversity, the VCS should be combined with other standards, such as the CCB Standards, FSC, PEFC, GCS or the SOCIALCARBON Standard based on the objectives of the project developers and the carbon credit buyers' preferences.

Figure 10. Summary of Voluntary Carbon Standard.

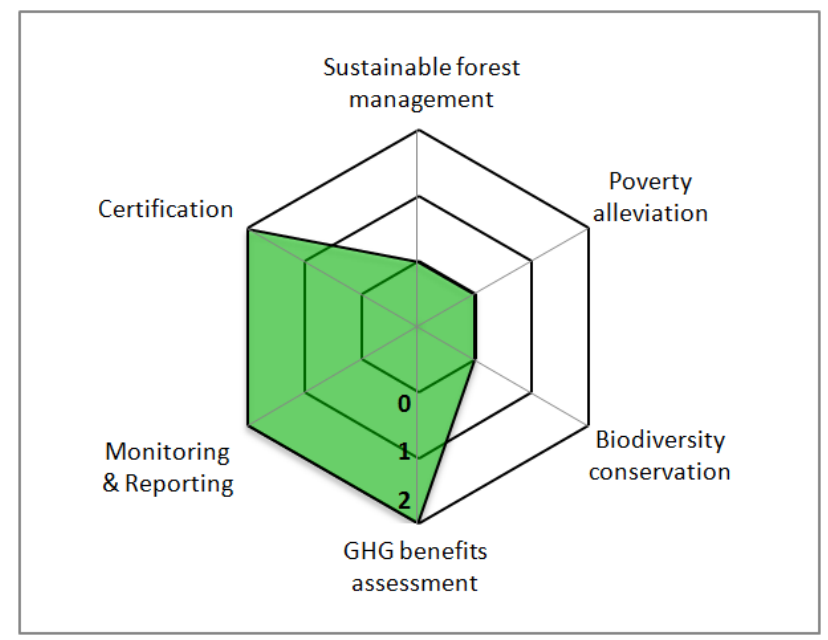




\section{Project Examples of Certification}

In the context of the present study and in parallel to its elaboration, a questionnaire was sent out to a number of REDD+ projects to assess the standard application in practice. The authors received feedback from two projects that we will present in the following:

\subsection{Madre de Dios Amazon REDD Project}

The Madre de Dios Amazon REDD Project, based in the Peruvian Amazon, spans around 100,000 hectares. It aims to sustainably manage an area that would otherwise be deforested. Madre de Dios started in May 2008, and it has a lifetime of 40 years. It was sponsored, developed, and implemented by the NGO Greenoxx in conjunction with other NGOs. The public image of the activity is thus of major importance to the project managers.

There is no single buyer of REDD+ offsets, and it is crucial to the project developers that the project be certified by the best-known standards, as they aim to convert the voluntary carbon offsets into compliance credits once an international compliance REDD+ regime is adopted. Forest management is being certified according to the FSC; the CCBA has validated the project at its "Gold Level"; and VCS auditing is planned. The developers observe that "in order to satisfy the requirements of most buyers, it is necessary to combine two or more standards, which results in higher costs and lengthens the time required to begin generating revenue from the carbon credits, which is critical to project implementation" [45]. Validation costs were US\$ 35,000 in the period between 2006 and 2009. For smaller projects, transaction costs tend to be prohibitive. The number of validators and verifiers is limited, and many methodologies are currently in the approval process.

Despite these barriers, Greenoxx judges the CCBA criteria to be very helpful in improving the biodiversity and community benefits. This example sheds light on the function of validation, which is an iterative process that eventually results in project approval.

\subsection{REDD Forests' Pilot Project: Protecting a Native Tasmanian Forest}

This project started in March 2009 and is aimed at preventing the deforestation of 790 ha within the 860 ha project area over a period of 30 years. The public image of the project is seen to be of overarching importance by the developers. The project currently aims to sell carbon credits through the voluntary market, but as it is located in Australia - an Annex I country under the UNFCCC - the project has aspirations on converting its voluntary credits into emission allowances under a forthcoming national emissions trading system or under a UN framework for forest carbon. Besides carbon, no other environmental services are quantified, although the conservation of biodiversity is an important marketing argument. The project developers chose to validate against the VCS and the CCB Standard, in addition to the national Carbon Pollution Reduction Scheme provided by the Government of Australia. Other standards were rejected because they were considered not to have the same recognition, authority or rigor. During the validation process, the Tasmanian project developers did not receive any assistance in improving social or environmental features of the project; they simply see it as a means to demonstrate compliance. 
The project developers consider VCS more essential for the sale of the REDD credits. Nevertheless, they criticize the long delays caused by the methodology approval procedures under the VCS, which has caused them cash-flow problems and thus provides "a disincentive to using carbon finance as a means to protect native forests" [46]. For a small project such as this one, it is projected to be 1.00 \$US for dual certification per carbon credit. There are dramatic economies of scale, as the size of the project area increases.

\subsection{Costs of Certification}

Generally, the cost of certification can range between 15,000 and 50,000 \$US [9], depending on the three major certification cost determinants: the complexity and the certification modalities of the standard, the quality of project documentation, the project type, size and regional dispersion. Therefore, it is difficult to estimate the costs according to the respective standards. Normally, third-party auditors estimate the cost on a project-specific basis after an auditing request of the project developers or a standard body. The costs depend on how many expert days are required to review the documents and conduct the field visits. As a rule of thumb, third-party auditors that are accredited under several of the mentioned accreditation programs normally charge a daily rate ranging between US\$ 500-1,500.

With respect to the standards' complexity and certification modalities, the costs of third party auditing depend on the comprehensiveness of the standard's regulations and their practicability. Standards that have easy to follow project documentation guidance and that provide straightforward tools and templates require less labor and expertise to prepare the requisite documentation and thus reduce transaction costs associated with preparing projects for certification.

In addition, the expertise and the ability of project developers to prepare project documentation that serves as the basis for third-party audits have significant impacts on the costs. Normally, the better the quality of the documents the validators receive the easier and more efficient it is to audit projects. In contrast, if poor quality project documentation is submitted, the interaction between project developers and auditors requires more efforts and time, thus increasing the costs. Therefore, the costs for project certification heavily depend on the efforts the auditor has to expend to review and prove the compliance of the project with the standard's criteria.

Finally, the project location and size is decisive for the cost, particularly with respect to field visits of auditors. If projects are large, in remote areas and are dispersed over several areas, they require more time and effort to collect representative samples within the project's boundaries. Accessibility and travelling conditions of the project areas are an important component of the costs and the more days an auditor has to spend on-site, the higher the costs of the audits.

Considering these three cost determinants of third party auditing, it becomes clear why auditing costs have such a high variability. Thus, instead of providing the cost ranges for third-party certification of different standards, a better estimate can be made based on the work that needs to be executed by third-party auditors. 


\section{Conclusions}

Within the UNFCCC REDD+ agreement that was concluded in Cancún, safeguards on REDD+ activities can become a major disincentive to implementation, as the circumstances and interests of countries are diverse and difficult to negotiate. In contrast, voluntary forest and carbon certification schemes can be seen an alternative to a prescribed safeguards policy, as the voluntary nature of standards puts pressure on standard setters to design standards that achieve an overall public acceptance by minimizing social, environmental and biodiversity risks and at the same time must not pose too high transaction costs on their application. This trade-off between achieving legitimacy and economic efficiency of standards is a major difficulty of standard setting and has led to specialized standards by project type, scope and modality.

In this paper, we have analyzed ten widely accepted standards for REDD+ related activities by initially identifying six criteria against we compared and evaluated the standards, which were Poverty alleviation, Sustainable Management of Forests, Biodiversity Protection, Quantification of net GHG Benefits, Monitoring and Reporting, and Certification Procedures.

The evaluation of standards within the hexagon of criteria has shown that no standard comprehensively and rigorously covers all six criteria. REDD programs require assessment of GHG benefits, monitoring and reporting and certification, and our analysis shows that only the VCS treats these three criteria comprehensively. Plan Vivo is complete for assessment of GHG benefits, monitoring and reporting, but does not provide for certification; CCB, ISO and PEFC provide for, monitoring, reporting and certification, but not for assessment of GHG benefits. This implies projects may fall short of market requirements if they use many of the standards that attempt to provide guidance in this area.

No standard provides comprehensive coverage of the other criteria that correspond to concerns expressed in the safeguards portion of the Cancún decision. FSC, PEFC and CarbonFix provide comprehensive assessments of the sustainable forest management criterion. CCBA REDD+ S\&E, CCB, and GCS provide comprehensive coverage of the biodiversity and poverty alleviation criteria. This implies that combining at least two certification schemes would be necessary in order to fully ensure social and environmental integrity of REDD+ activities. The combination of standards depends on the project modalities (carbon stock conservation, management, or enhancement), the project scale (smallscale or large-scale), its scope (national or subnational), and the expectations and objectives of the prospective sponsors or buyers of carbon credits. Considering these aspects, we have provided recommendations on which standards might be worthwhile to combine.

Looking toward the future, and taking into account that various experiences with application of these standards to date, there appears a need to streamline certification criteria and procedures in order to make forest and REDD+ certification more economically efficient and at the same time guarantee sufficient social and environmental safeguards. Such a reconciliation process would result in a more harmonized quality of REDD+ projects or programs. This could be achieved through reciprocal partnerships and strategic alliances between the certification schemes. For a project developer it is of utmost importance to consider certification early in the design phase, because retrofitting a project to meet certification requirements later will likely lead to increased costs and delays. Furthermore, considering the international REDD+ negotiations under the umbrella of the UNFCCC, practical 
experience in forest and carbon certification could provide useful information to support the design of modalities for the international REDD+ regime.

\section{Acknowledgements}

Funding for this work was generously provided by grants to CIFOR from the governments of Australia (AusAID 46167), France (Agence Française de Dévelopement No. CZZ 1450.01 X) and Norway (NoradNo. QZA-10/0468). The authors want to express their gratitude for the comments received from Elena Petkova and three anonymous peer reviewers.

\section{References}

1. Stern, N. Stern Review on the Economics of Climate Change; Cabinet Office-HM Treasury: London, UK, 2006.

2. Modalities and Procedures for Afforestation and Reforestation Project Activities under the Clean Development Mechanism in the First Commitment Period of the Kyoto Protocol; United Nations Framework Convention on Climate Change (UNFCCC): Bonn, Germany, 2003.

3. Dutschke, M.; Schlamadinger, B.; Wong, J.; Rumberg, M. Value and risks of expiring carbon credits from afforestation and reforestation projects under the CDM. Clim. Policy 2005, 5, 109-125.

4. United Nations Framework Convention on Climate Change (UNFCCC). Manuscript prepared for the Ad Hoc Working Group on Long-term Cooperative Action under the Convention, Tianjin, China, 4-9 October 2010.

5. Walter, M.; Kahlert, G. Forest Carbon Standards-A WWF Assessment Guide; WWF Germany: Frankfurt/Main, Germany, 2010.

6. Held, C.; Tennigkeit, T.; Techel, G.; Seebauer, M. Analyse und Bewertung von Waldprojekten und entsprechender Standards zur freiwilligen Kompensation von Treibhausgasemissionen; Deutschen Emissionshandelsstelle Umweltbundesamt: Dessau-Roßlau, Germany, 2010.

7. Kollmuss, A.; Lazarus, M.; Lee, C.; Polycarp, C. A Review of Offset Programs: Trading Systems, Funds, Protocols, Standards and Retailers; Research Report; Stockholm Environment Institute: Stockholm, Sweden, 2008; Version 1.1.

8. Lopes, P. Review of Forestry Carbon Standards-Development of a Tool for Organizations to Identify the Most Appropriate Forestry Carbon Credit; Imperial College London: London, UK, 2009.

9. Merger, E. Forestry Carbon Standards 2008-A Comparison of the leading Standards in the Voluntary Carbon Market and the State of Climate Forestation Projects; Carbon Positive: Sydney, Australia, 2008.

10. Green carbon guidebook. In World Wildlife Fund International; Rietbergern-McCracken, J., Ed.; WWF International: Gland, Switzerland, 2008.

11. Van Kuijk, F.; Putz, E.; Zagt, R.J. Effects of Forest Certification on Biodiversity; Tropenbos International: Wageningen, The Netherlands, 2009.

12. Gulbrandsen, L.H. Overlapping public and private governance: Can forest certification fill the gaps in the global forest regime? Global Environ. Polit. 2004, 4, 75-99. 
13. Moving Ahead with REDD: Issues, Options and Implications; Angelsen, A., Ed.; CIFOR: Bogor, Indonesia, 2008.

14. Brown, D.; Seymour, F.; Peskett, L. How do we achieve REDD co-benefits and avoid doing harm? In Moving Ahead with REDD: Issues, Options and Implications; Angelsen, A., Ed.; CIFOR: Bogor, Indonesia, 2008; p. 158.

15. FSC International Standard-Principles and Criteria for Forest Stewardship; Forest Stewardship Council (FSC): Bonn, Germany, 1996.

16. ISO 14064-2, 1st ed.; International Standardization Organization (ISO): Geneva, Switzerland, 2006.

17. ISO 14064-3, 1st ed.; International Standardization Organization (ISO): Geneva, Switzerland, 2006.

18. Rules for Standard Setting Annex 2; Programme for the Endorsement of Forest Certification Council (PEFC): Girondins, Luxembourg, 2006; Volume 27.

19. Strategic Plan for the PEFC Council; Programme for the Endorsement of Forest Certification Council (PEFC): Girondins, Luxembourg, 2007.

20. Climate, Community \& Biodiversity Project Design Standards, 2nd ed.; Climate Community and Biodiversity Alliance (CCBA): Arlington, VA, USA, 2008.

21. The Plan Vivo Standards 2008, 2008 ed.; Plan Vivo Foundation: Edinburgh, UK, 2008.

22. Voluntary Carbon Standard-Specification for the Project-Level Quantification, Monitoring and Reporting as well as Validation and Verification of Greenhouse Gas Emission Reductions or Removals; Voluntary Carbon Standard Association: Washington, DC, USA, 2008.

23. Voluntary Carbon Standard Guidance for Agriculture, Forestry and Other Land Use Projects 18th November 2008; Voluntary Carbon Standard Association: Washington, DC, USA, 2008.

24. CarbonFix Standard. CarbonFix Standard Version 3.0; CarbonFix e.V.: Stuttgart, Germany, 2009.

25. REDD+ Social and Environmental Standards-Social and Environmental Standards for REDD and other Forest Carbon Programs, 2nd ed.; Climate Community and Biodiversity Alliance (CCBA): Arlington, VA, USA, 2009.

26. FSC Statutes Document 1.3; Forest Stewardship Council (FSC): Oaxaca, Mexico, 2009.

27. SOCIALCARBON Team. Social Carbon Standard, 4th ed.; SOCIALCARBON®: São Paulo, SP, Brazil, 2009.

28. The CarbonFix Standard: Quality $\mathrm{CO}_{2}$-Certificates from New Forests; CarbonFix e.V.: Stuttgart, Germany, 2011; Available online: http://www.carbonfix.info/CarbonFix-Standard/Structure.html? PHPSESSID=m6d2v39nleh0og5qk2lsrhjgg2 (accessed on 7 April 2011).

29. REDD+ Social \& Environmental Standards, Version 1 June 2010 ed.; Climate Community and Biodiversity Alliance (CCBA): Arlington, VA, USA, 2010.

30. The Global Conservation Standard Version 1; Global Conservation Standard (GCS): London, UK and Offenburg, Germany, 2010; Volume 14.

31. Jennings, S.; Nussbaum, R.; Judd, N.; Evans, T.; Azevedo, T.; Brown, N.; Colchester, M.; Iacobelli. T.; Jarvie, J.; Lindhe, A.; et al. The High Conservation Value Forest Toolkit; 1st ed.; ProForest: Oxford, UK, 2003; Volume 1.

32. Winkler, H. Measurable, reportable and verifiable: The keys to mitigation in the Copenhagen deal. Clim. Policy 2008, 8, 534-547.

33. Guidelines PEFC Council Minimum Requirements Checklist, GL 2/2010 ed.; Programme for the Endorsement of Forest Certification (PEFC): Girondins, Luxembourg, 2010. 
34. Auld, G.; Gulbrandsen, L.H.; McDermott, C.L. Certification schemes and the impacts on forests and forestry. Annu. Rev. Env. Resour. 2008, 33,187-211.

35. Tool for AFOLU Non-Permanence Risk Analysis and Buffer Determination; Voluntary Carbon Standard Association: Washington, DC, USA, 2008.

36. CarbonFix Standard. CFS Methodology (Background Information. CFS Version 3.0); CarbonFix e.V.: Stuttgart, Germany, 2009.

37. Certification and Accreditation Procedures Annex 6, 27 October 2006 ed.; Programme for the Endorsement of Forest Certification (PEFC): Girondins, Luxembourg, 2007.

38. Tool for AFOLU Methodological, Issues 18 November 2008, 2007.1 ed.; Voluntary Carbon Standard Association: Washington, DC, USA, 2008.

39. VCS Guidance Document: VCS Project Registration and VCU Issuance Process, Version 1.1; Voluntary Carbon Standard Association: Washington, DC, USA, 2009.

40. 5 Steps Towards FSC Certification; Forest Stewardship Council (FSC): Bonn, Germany, 2011; Available online: http://www.fsc.org/5-steps-certification.html (accessed on 7 April 2011).

41. Get PEFC Certified; Programme for the Endorsement of Forest Certification (PEFC): Girondins, Luxembourg, 2011; Available online: http://www.pefc.org/index.php/certification-services/ supply-chain/get-pefc-certified (accessed on 7 April 2011).

42. CarbonFix Standard. Combined Certifications (Background Information, CFS Version 3.0), 3.0 ed.; CarbonFix e.V.: Stuttgart, Germany, 2009.

43. CCBA. Rules for the use of the Climate, Community \& Biodiversity Standards; The Climate, Community \& Biodiversity Alliance: Arlington, VA, USA, 2010.

44. Decision 11/CP.7 Land Use, Land-Use Change and Forestry. Presented at the Conference of the Parties on its Seventh Session, Marrakesh, Morocco, 29 October-10 November 2001; United Nations Framework Convention on Climate Change (UNFCCC): Bonn, Germany, 2001; pp. 54-63.

45. Silvia Gomez Caviglia, Greenoxx, personal communication, 2010.

46. Stephen Dickey, REDD Forests Pty Ltd, personal communication, 2010.

(C) 2011 by the authors; licensee MDPI, Basel, Switzerland. This article is an open access article distributed under the terms and conditions of the Creative Commons Attribution license (http://creativecommons.org/licenses/by/3.0/). 